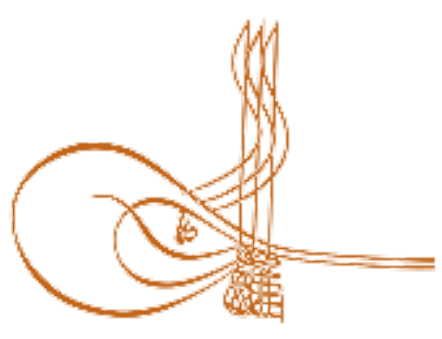

www.turkishstudies.net/education
Turkish Studies - Educational Sciences

eISSN: 2667-5609

Research Article / Araștırma Makalesi

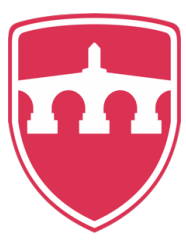

INTERNATIONAL BALKAN

UNIVERSITY

Sponsored by IBU

\title{
Çocuk Eğitiminin Konu İçerikleri ve İlkeleri Bakımından Gazali ve İbn Haldun'un Düşüncelerinin Karşılaştırılması
}

\author{
Comparison of The Thought of Gazali and Ibn Haldun in Terms of Content and Principles of Child \\ Education
}

\author{
Aytekin Demircioğlu ${ }^{*}$
}

\begin{abstract}
Children's education has always maintained its importance and popularity in terms of Islamic philosophy. Islamic thinkers paid particular attention to what subjects children should be educated and what they would include. The central point of child education in Islamic thought is religious education. This is often considered equivalent to Quranic education. While most Islamic thinkers have shaped their understanding of education on the basis of the Qur'anic education, some have stated that other subjects may be added to it. Islamic thinkers, who could meet in a common ground on the necessity of religious education, also adopted different styles about the principles and methods of education. The age of child education in Islamic thought is not clearly defined. However, the age of commencement of education is usually around five to seven years of age and the end time is when the child enters puberty. Since the child, who is entering adolescence, is considered an adult in terms of Islamic culture, the idea that he should continue his education in accordance with his own preferences and abilities is adopted. Al-Ghazali and Ibn Khaldun, the important representatives of Islamic philosophy, also attached special importance to the issue of child education. In this study, the ideas of Ghazali and Ibn Khaldun about which subjects and contents should be taught to children and which principles and methods should be teach. The findings were mostly obtained through the content analysis technique of first-hand sources, and a comparative and critical perspective was used in the interpretations.
\end{abstract}

Structured Abstract: Children's education has always maintained its importance and popularity in terms of Islamic philosophy. Islamic thinkers paid particular attention to what subjects children should be educated and what they would include. The central point of child education in Islamic thought is religious education. This is often considered equivalent to Quranic education. While most Islamic thinkers have shaped their understanding of education on the basis of the Qur'anic education, some have stated that other subjects may be added to it. Islamic thinkers, who could meet in a common ground on the necessity of religious education, also adopted different styles about the principles and methods of education.

\footnotetext{
* Doç. Dr., Kastamonu Üniversitesi, İlahiyat Fakültesi, Felsefe ve Din Bilimleri Bölümü Assoc. Prof. Dr., Kastamonu University, Faculty of Theolgy, Philosophy and Religious Sciences Department ORCID 0000-0003-4945-5519

demircioglu.aytekin@gmail.com

Cite as/ Atıf: Demircioğlu, A. (2020). Çocuk eğitiminin konu içerikleri ve ilkeleri bakımından Gazali ve İbn Haldun'un düşüncelerinin karşıslaştırılması, Turkish Studies - Education, 15(2), 765-781. https://dx.doi.org/10.29228/TurkishStudies.39289

Received/Geliş: 15 October/Ekim 2019

Accepted/Kabul: 12 March/Mart 2020

Copyright $(\mathrm{C}$ INTAC LTD, Turkey 
The age of child education in Islamic thought is not clearly defined. However, the age of commencement of education is usually around five to seven years of age and the end time is when the child enters puberty. Since the child, who is entering adolescence, is considered an adult in terms of Islamic culture, the idea that he should continue his education in accordance with his own preferences and abilities is adopted.

Al-Ghazali and Ibn Khaldun, the important representatives of Islamic philosophy, also attached special importance to the issue of child education. In this study, the ideas of Ghazali and Ibn Khaldun about which subjects and contents should be taught to children and which principles and methods should be teach. The findings were mostly obtained through the content analysis technique of first-hand sources, and a comparative and critical perspective was used in the interpretations.

Ghazali was a sufist person. During his adventure to reach the truth, he studied Kalam, Philosophy, Batinism and Mysticism, and criticized some of the misconceptions of his members, but decided that mysticism was the right means to bring it to truth. In this respect, it can be said that his views on child education are of Sufi nature.

Although Gazali comes from a Sufi tradition, it cannot be interpreted as a classical conservative in terms of his view of events. In particular, it can be said that his views on education are based on a modern perspective that goes beyond the age. He has an exceptional place among the intellectuals in the Islamic World.

Al-Ghazali has often addressed educational issues in both Ihya and other works. If today's terminology is used, it can be said that Ghazali advocates the principle of lifelong learning. Because its educational target group includes people of all ages.

Ibn Khaldun is a thinker whose Islamic sensitivities are at the forefront. He remained faithful to the principle of monotheism from the beginning to the end of Mukaddime. In this context, it can be said that his views on education are shaped within the tradition of Islamic education. However, the fact that he opposes the use of violence in education and emphasizes that other information should be taught to children before the Qur'an indicates that he, as in many other subjects, has exceeded his age and culture in education.

Islamic thinkers often did not devote much to the principles, methods, and issues when dealing with issues related to education and training. This also applies to Ghazali and Ibn Khaldun. This situation is more pronounced especially in Ghazali. Subject and teaching methods are intertwined and mixed in his thoughts. Sometimes the subject is meant by the method, sometimes by the procedure is the content of education.

The main subject of children's education is the Qur'an for both thinkers due to their period and due to their religious scholars. Al-Ghazali has added Qur'an, Kiraat (Beautiful and true reading of the Qur'an), Siyer (Life of the Prophet) and the Companions of the Companions to his Qur'an education. Ibn Khaldun sees the Qur'an education and the Qur'an the same. He considered it necessary to add subjects such as Fine Writing, Arabic, Poetry, Calculation, Fiqh, Cedel (Scientific Discussion).

Although both of the studied thinkers are scholars of religion, the emphasis in Ghazali is more religious. Ibn Khaldun showed a more scientific approach to the event and acted from his observations and facts. According to him, education is one of the natural conditions in society.

There are several similarities between the views of both thinkers in terms of learning methods and techniques. For example, they agree on a number of methods, such as gradual teaching, start from easy subjects to the difficulties, transferring subjects by a master, taking into account individual differences in students.

On the other hand, there are areas where Ghazali and Ibn Khaldun think differently about education. For example, Gazali states that despite all positive ways to be tried and persisted in these methods, if the student continues in the wrong way, hardness can be resorted to. Ibn Khaldun stood against violence and harshness in education. Again, Ghazali brought the family and house to the forefront in children's education, while Ibn Khaldun put more emphasis on madrasas and schools in education. Another point where the thinkers are separated is the subject of poetry. While Ghazali is totally opposed to the teaching of poetry, Ibn Khaldun sees poetry as an area that must be taught to children. 
While Ghazali has a more traditional appearance in child education, Ibn Khaldun has a more innovative profile. The fact that Ibn Khaldun brought some firsts and innovations to the field of education is an indicator of this. For example, for the first time, he used the concepts of primary and secondary education to draw attention to the levels of education. Again, winning an ability in a branch of science is an important concept used instead of "full learning". It is also an offer that can be expressed as radically innovative in terms of when it tells children that basic grammar and calculus rules should be taught before Quranic education.

Ibn Khaldun insisted on the faults that will expel the student from science. According to him, the most common mistake of scholars is to apply a curriculum that is not appropriate to the students' capacity and to put them under unnecessary responsibility, which may remove down the demand from science and learning. It is a common issue that both thinkers care about not remove students from science.

As a result, in this study, where the ideas of Ghazali and Ibn Haldun are confronted in the context of the subjects, content and principles of child education, both thinkers have similar and different views.

Key Words: Education, Islamic Philosophy, Value Education, Ghazali, Ibn Khaldun

Öz: Çocuk eğitimi, İslam felsefesi açısından her zaman önemini ve popülerliğini korumuş bir konudur. İslam düşünürleri, çocukların hangi konularda eğitilmeleri gerektiği ve bu konuların neleri içereceği konusuna özel bir önem vermişlerdir. İslam düşüncesinde çocuk eğitiminin merkez noktası din eğitimidir. Bu, çoğu zaman Kur'ân eğitimi ile eş değer kabul edilmiştir. İslam düşünürlerinin çoğu, eğitim anlayışlarını Kur'ân eğitimi ekseninde şekillendirirken bazıları buna başka konuların da ilave edilebileceğini belirtmişlerdir. Din eğitiminin gerekliliği konusunda ortak bir paydada buluşabilen İslam düşünürlerinin eğitimin ilke ve yöntemleri konusunda farklı tarzları benimsedikleri de olmuştur. İslam düşüncesinde çocuk eğitiminin hangi yaşları kapsadığı çok net sınırlarla çizilmemiştir. Bununla birlikte eğitime başlama yaşı genellikle beş - yedi yaş civarı olup bitiş zamanı çocuğun buluğ çağına (ergenlik) girmesiyledir. Ergenlik çağına giren çocuk, İslam kültürü açısından yetişkin kabul edildiği için bundan sonraki eğitimine kendi tercihiyle ve yetenekleri doğrultusunda devam etmesi gerektiği fikri benimsenmiştir. İslam felsefesinin önemli temsilcileri olan Gazali ve İbn Haldun da çocuk eğitimi konusuna özel bir önem vermişlerdir. Bu çalışmada Gazali’nin ve İbn Haldun'un çocuklara hangi konuların ve içeriklerin, hangi ilke ve yöntemlerle öğretilmesi gerektiği konusundaki düşünceleri ele alınmıştır. Bulgular daha çok birinci el kaynakların içerik analizi tekniği ile elde edilmiş olup yorumlamalarda, karşılaştırma ve eleştirel bir bakış açısı kullanılmıştır.

Anahtar Kelimeler: Eğitim, İslam Felsefesi, Değerler Eğitimi, Gazali, İbn Haldun

\section{Giriş}

Gazali, 1058 ile 1111 yılları arasında yaşamış ünlü bir din âlimidir. Gazali'nin hayatı dini meseleleri açıklamak ve İslam'a zarar veren görüş ve uygulamalarla mücadele etmekle geçmiştir. O bir yandan geniş halk kitlelerine İslam'ı anlatmaya ve açıklamaya çalışmış, diğer yandan da hem İslam âlemi içinden hem de dışarıdan İslam'ın özüne zarar veren görüş ve uygulamalara savaş açmışıtır.

Gazali'nin İslam'a zarar verdiği gerekçesiyle mücadele ettiği gruplar arasında kelam, felsefe, Batınilik ve tasavvuf bulunmaktadır (Çağrıcı, 1996). Bu bağlamda, eğitim konusundaki görüşleri onun İslam'ı anlatma çabasının bir uzantısı olarak düşünülebilir. Gazali fikıhtan kelama, mantıktan felsefeye kadar birçok konuda çok sayıda eser yazmıştır. Yazdığı veya ona isnat eserler o kadar çoktur ki, eserlerinin sayısı tam olarak tespit edilememektedir (Karlığa, 1996). Gazali'nin bu eserleri arasında İslam'ı özüne uygun anlatmak ve dini ilimlere yeni bir soluk katmak için yazdığı eser Ihya-u Ulumid'din'dir.

$\mathrm{O}$, hakikate ulaşma serüveni esnasında kelam, felsefe, Batınilik ve tasavvufu incelemiş ve mensuplarının bazı yanlış uygulamalarını eleştirmekle beraber hakikate ulaştıracak doğru aracın tasavvuf olduğuna karar vermiştir (Uludağ, 1996). Bu doğrultuda, onun çocuk eğitimi konusundaki görüşlerinin tasavvufi bir nitelik taşıdığı söylenebilir. 
Gazali her ne kadar tasavvufi bir gelenekten gelse de olaylara bakışı itibariyle klasik bir muhafazakâr olarak yorumlanamaz (Aydınlı, 2015). Özellikle eğitim konusundaki görüşlerinin çağını aşan modern bir perspektife dayandığı söylenebilir. O, İslam Dünyasındaki aydınlar arasında müstesna bir yere sahiptir (Watt, 2003).

Gazali hem İhya'da hem de diğer eserlerinde eğitimle ilgili konulara sıç̧a değinmiştir. Bugünkü terminoloji kullanılacak olursa, Gazali’nin yaşam boyu ögrenme ilkesini savunduğu söylenebilir. Zira onun eğitimle ilgili hedef kitlesinde her yaştan insanlar yer almaktadır.

1332'de Tunus'ta doğup 1406'da Misır'da vefat eden İbn Haldun da Gazali gibi iyi bir ilim ehlidir. Bununla birlikte dini ilimlerde Gazali kadar şöhret sahibi değildir. Her ne kadar Maliki baş kadılı̆̆ yapmış olsa da o daha çok sosyal ve siyasal alanlarda dile getirdiği orijinal fikirleriyle tanınmıştır.

İbn Haldun'un kendi hayatı hakkında verdiği bilgilerden yola çıkarak iyi bir ilim tahsil ettiği anlaşılmaktadır. Onun ilmi başarısı ve parlak zekâsı, iletişim ve ikna kabiliyetleri siyasilerin gözünden kaçmamış ve kendisine çoğu zaman devlet yöneticilerinin yanında siyasi görevler verilmiştir (İbn Haldun, 2011). İbn Haldun sahip olduğu meziyetleri kendi şahsi menfaatlerinin temini ve tesisi konusunda iyi kullanmayı bilen biridir. Bu hırslı tavrı bazen yanlış siyasi kararlar almasına ve çeşitli sıııntılar çekmesine de yol açmıştır.

Her ne kadar siyasal hırsları onu çeşitli sorunlarla mücadele etmek zorunda bıraksa da İbn Haldun birçok alanda orijinal fikirler üretmeyi başarmıştır. Bu fikirleri üretmesinde şüphesiz devlet adamlığının kendisine kazandırdığı tecrübeler yanında çok gezen, okuyan ve olgusal gözlemlere çağını aşacak şekilde kıymet veren ilim yapma tarzı etkili olmuştur.

İbn Haldun, ilm-i umran adıyla yeni ve orijinal bir ilim dalı kurduğunu ve bununla arkadan gelecek araştırmacıların yolunu aydınlattığını iddia etmiştir (İbn Haldun, 2009). Gerçekten de $i l m-i$ umran'ın hareket sahası o kadar geniştir ki, İbn Haldun bu sayede birçok ilim dalının kurucusu sayılmıştır.

Görüş beyan ettiği alanların genişliği sebebiyle İbn Haldun'u tarihçi, tarih teorisyeni, sosyolog, iktisatçı, şehir planlamacısı, hukukçu, siyasetçi, ilahiyatçı vb. olarak adlandıranlar olmuştur (Uludağ, 2014). İfadelerde gücü arttırarak onu tarih biliminin gerçek kurucusu, politik iktisadın kurucusu ve çağdaş anlamda ilk siyaset bilimci olarak tanımlayanlar da vardır (Hassan, 2019). İbn Haldun bazılarına göre sosyolojinin kurucusu unvanını Comte'dan daha çok hak etmektedir (Husri, 2001). Bunların yanında İbn Haldun'u, İbn Sina ve Machiavelli ile kıyaslayanlar olmuştur (Morris, 2009). Ayrıca onun Kant ve Hume gibi birçok batılı düşünürü öncelediği yönünde görüşler dile getirilmiştir (Choudry \& Silvia, 2008; Sarıbaş, 2007).

Bütün bunların yanında İbn Haldun, İslami hassasiyetleri ön planda olan bir düşünürdür. $O$, Mukaddime'nin başından sonuna kadar tevhit ilkesine sadık kalmıştır (Şulul, 2011). Bu bağlamda, onun eğitim ile ilgili görüşlerinin İslami eğitim geleneği içinde şekillendiği söylenebilir. Bununla birlikte, eğitimde şiddetin kullanılmasına karşı çıkması ve Kur'ân'dan önce çocuklara başka bilgilerin öğretilmesi gerektiğine vurgu yapması, onun birçok konuda olduğu gibi, eğitim konusunda da çağını ve içinde bulunduğu kültürü aştı̆̆ının göstergesidir. Çünkü dönem itibariyle temel eğitim çağındaki çocuklara öğretilen yalnızca Kur'an'ın düzgünce okunması ve çeşitli dini bilgilerden ibarettir (İbn Haldun, 2009)

Çalışmamıza konu olan her iki alim de bireysel anlamda birbirinden çok farklı konularda görüşleri olan ve bu görüşleriyle hem Müslüman dünyada hem de Müslüman olmayan dünyada geniş etki uyandırmış ve saygı görmüş kilerdir. Onlar eğitimden politikaya, sosyolojiden tarihe, dini ilimlerden pozitif ilimlere varıncaya kadar pek çok alanda görüşler serdetmişler ve bu görüşleriyle pek çok kişiyi etkilemişlerdir. 
Gazali'nin etkilediği kişiler arasında R. Martini, Juda Halevi, İbn-i Meymun, Descartes, Pascal, Spinoza, Leibniz, Berkeley, David Hume, Malebanche, Clarke, Ebu'l Farec, Joseph Albo, Abraham Bibago, Isaac Abravanel, Crescas, Rabbi, Mosê, Bergson ve Kant gibi isimler say1labilir (Uludağ, 2000; Bolay, 2005).

İbn Haldun da benzer şekilde geniş etki yaratmış bir düşünürdür. Batıda ise ilk defa Fransız düşünür Silvestre de Sacy, 1806'da Mukaddime'den bahsetmiştir. Stefano Colosio İbn Haldun'u Machiavelli ile karşılaştırmıştır. Batılı düşünürlerden J. Von Hammer, Mukaddime'yi Türkçe tercümesinden okur okumaz, İbn Haldun için 'Arapların Motesquieu'su' yakıştırmasını yapmıştır (Adivar, 1940).

Osmanlı ulemasından Kâtip Çelebi, Naima, Taşköprüzade, Müneccimbaşı, Hayrullah Efendi ve Cevdet Paşa gibi düşünürler, Mukaddime'yi başucu kitabı yapmışlardır (Okumuş, 2006).

Makrizi, İbn Tağriberdi, Kalkaşendi ve İbn Azrak gibi yazarlar İbn Haldun’u tanımış ve ondan yararlanmışlardır (Uludağ, 2014).

On dokuzuncu yüzyılda Garcin de Tassy tarafinda birkaç bölümü tercüme edilen Mukaddime'yi özet halinde Fransizcaya çeviren Quatremére, onu Prolégonémes adiyla yayımlamıştır. Eserin Batı dillerine tam tercümesini ilk defa Baron de Slane yapmıștır. Bundan sonra Avrupa'da, Mukaddime ve İbn Haldun çok bilinir bir hale gelmiştir (Ülken, 2015).

İbn Haldun'un insan doğası ve devletin ortaya çıkış gerekçeleri ile ilgili düşünceleriyle, Grotius ve Locke gibi klasik liberalizmin kurucularının görüşleri arasında önemli bir benzerlik bulunmaktadir (Toku, 2002).

A. von Kremer 1879 'da Mukaddime 'yi, İslam imparatorluklarının bir 'Kulturgeschichte'si (kültürel geçmiş) olarak nitelemesinden sonra, R. Flint, tarih felsefesinin tarihini incelerken Mukaddime üzerinde dikkatle durmuş ve ondan övgüyle bahsetmiştir. Yirminci yüzyılın başlarında İslam felsefe tarihini inceleyen T. J. de Boer, İbn Haldun'un mantığı ele alış biçiminin 'dikkatle incelenmeye değer' olduğunu söylemiştir (Hassan, 2019).

İşte bu iki düşünürün bu çalışmaya konu edinmelerinin nedeni onların oluşturduğu geniş etki ve eğitim konusundaki görüşlerinin daha önce birlikte ele alınmayışının getirdiği orijinalliktir.

\section{Yöntem}

Bu çalışmada, çocuk eğitiminde kullanılan konu içeriklerin neler olduğu ve bu eğitimin dayandığ 1 ilkeler Gazali ve İbn Haldun özelinde tespit edilerek iki düşünürün bu konulardaki görüşleri karşılaştırılmaya çalışılmıştır. Bununla birlikte çalışmada Gazali'nin ve İbn Haldun'un çocuk eğitimi ile ilgili ele aldıkları konu içeriklerinin ve ilkelerinin birebir aynı olduğu yönünde bir varsayım bulunmamaktadır. Bu nedenle bu çalışmadaki karşılaştırma her iki düşünürün eğitsel konu içeriklerini ve ilkeleri nasıl anladıkları ve işledikleri üzerine kuruludur.

Çocuk eğitimiyle ilgili zaman aralığ 1 bu düşünürlerce net sınırlandırılmamış olup, çalışmamızda, beş - yedi yaş civarında başlayarak çocuğun ergenliğe girdiği on üç - on altı yaş civarına kadar devam eden eğitim dönemi olarak kabul edilmiştir.

Çalışmaya esas teşkil eden bulgular, Gazali ve İbn Haldun'un kendi eserlerinin sosyal bilimlerde sıkça kullanılan yorumlama ve eleştiri teknikleri kullanılarak incelenmesiyle oluşturulmuştur.

\section{Gazali’ye Göre Çocuk Eğitiminin Konu İçerikleri ve İlkeleri}

Gazali XI. Yüzyılda yaşamış bir düşünürdür. Öğrenciler için bu dönemde eğitim almanın ve bu yolda ilerlemenin birinci yolu bir alimin yanına giderek onun derslerine dahil olmaktı. O alimin okuttukları bitince başka bir alimin yanına gidilir veya eğitimin daha sistematik halde 
verildiği medreselere gidilirdi. Bu durum Gazali'nin yaşantısında da benzer şekilde cereyan etmiştir. Önce yakın yerlerdeki alimlerden bazı dersler almış daha sonra ilmini genişletmek için medrese talebesi olmuştur (Gazali, 2020).

İslam, güçlü bir biçimde insanları ilim öğrenmeye ve öğretmeye teşvik etmiştir. Çünkü Allah ancak ilimle bilinebilir ve Allah'a ibadet de ancak ilimle yapılır. Bu nedenle ilim nurdur. İlmi aramak cihat, onu tahsil etmek ibadet, bilmeyene öğretmek sadakadır. Yüce Allah, kavimleri ve insanları ancak ilimle yüceltmekte ve başka kavim ve insanlara üstün kılmaktadır. $\mathrm{Bu}$ nedenle Allah katında konumu en yüksek olan kimseler ilim sahibi olanlardır (Gazali, 2012).

İslam, insanları ilim öğrenmeye yalnızca teşvik etmemiş, ayrıca ilim öğrenmeyi zorunlu kılmıştır. Bu nedenle ilim öğrenme sürecine dâhil olan öğretmen ve öğrencilere önemli vazifeler yüklenmiş̧ir. Buna göre ilim öğreten âlimler her şeyden önce öğrencilerini iyi gözlemlemeli ve öğretme yöntemlerini öğrencinin kişiliğine göre şekillendirmelidir. Öğrenciler de ilim öğrenme konusunda hevesli olmalı, öğretmenlerine saygıda kusur etmemelidir (Gazali, 2014).

Çocuk eğitiminde anne - babalara da düşen önemli vazifeler vardır. Aile her şeyden önce geçimlerini helal yollardan sağlamalı ve çocuklarının rızkına haram bulaştırmamalıdır. Çocuklarına iyi birer isim vermeli, onlara örnek olmalı, çocukları arasında adaletli davranmalı ve onlara güzel ahlak kazandırma konusunda gayret etmelidir (Gazali, 2001).

Gazali, İhya'nın üçüncü cildinde çocuk eğitiminin konularının ve içeriklerinin tespiti için müstakil bir bölüm ayırmıştır. Burada çocuk eğitimin on sekiz ana konu etrafında şekillendirilmesi gerektiğini anlatmıştır. Bu konular şöyledir (Gazali, 2004):

Çocuklar helal gıda ile beslenmelidir. Çünkü çocukların yedikleri yiyecekler onların ruhlarına etki eder. Haram gıda ile beslenen çocukların körpe ruhları bozulur ve harama karşı meyilli olurlar. Gazali'ye göre bu o kadar bariz bir etkidir ki, çocuğu annesinden başka biri emzirecekse, bu sütannenin helal - haram ile olan bağlantısı da çocuğa geçer.

Çocuğun akıl nuru parlamaya başladığı andan itibaren ona iyi, güzel davranışlar kazandırmaya çalışılmalıdır. Bunun için ebeveynler kendi hayatlarından dikkat çekici, inandırıcı ve güzel örnekleri çocuklara göstermelidirler. Gazali’nin burada çocuğun akıl nuru parlamaya başladiğı an ile tam olarak kaç yaşını kastettiği belirsizdir. Ancak çocuğun konuşmayı öğrendiği ve bilinçli sorular sormaya başladığ 1 iki yaşından sonraki dönem olması muhtemeldir. Gazali'nin burada dikkat çektiği bir başka önemli husus da çocuklarından iyi davranışlar bekleyen ebeveynlerin öncelikle bu iyi davranışları kendilerinin yaparak çocuklarına örnek olmaları gerektiğidir.

Çocuklara çok yemenin zararları çocuklara anlatılmalıdır. Yemeğin insanın sağlı̆̆ını devam ettirebilmesini ve ibadetleri aksatmamasını sağlayacak kadar olması gerektiği, fazlasının hamallıktan farklı olmadığı söylenmelidir. Bu amaçla bazen sadece ekmek ile öğün geçiştirilmeli, sofraya başkaca yiyecek konulmamalıdır. Böylece çocuk, her zaman çeşitli yemekler bulamayabileceğini ve azla kanaat etmesi gerektiğini öğrenmelidir. Gazali burada temel İslam kaynaklarının hepsinde anlatılan (İbn Mace, Et'ime: 50; Tirmizi, Zühd: 47) ve İslam düşünürlerinin birçoğunun (Erzurumlu İbrahim Hakkı, 2019) açıklamaya çalıştığı çok yemenin zararları üzerinde durmuş ve az yeme alışkanlığının küçük yaşlardan itibaren çocuklara kazandırılması gerektiğini savunmuştur.

Çocuğa örnek göstermenin öneminden hareketle onun yanında iyi huylu ve terbiyeli başka çocukları övmelidir. Gazali bu yolla çocuğun yanında övülen diğer çocukları örnek alacağını ummaktadır. Ancak bunun her zaman böyle olmayabilir. Övgünün yeri, zamanı ve dozajı iyi ayarlanmazsa çocukta örnek alma davranışı yerine kıskanma davranışı gelişebilir.

Çocuğun iyi arkadaşlar edinmesine yardımcı olmadır. Çocuk iyi huylu, terbiyeli çocuklarla arkadaşlık ederse onlar gibi olur; kötü huylu, yalan söyleyen, ağzı bozuk arkadaşlar edinirse de 
onlar gibi olur. Bu çocuk eğitiminde her zaman geçerli olmuş, düşünürlerin üzerinde hemfikir olduğu bir konudur (Acar, 2017; Yavuzer, 2016; Ogelman 2014; Kamhi, 2013; Şener, 2006; Dodson, 1999).

Çocuğa Kur'ân okuması öğretilmeli, dini ve ahlaki kitaplar okuması teşvik edilmeli, âlim ve salih kimselerin sohbetlerine götürülerek onda bu kimselere karşı sevgi ve muhabbet oluşması sağlanmalıdır. Gazali'nin bu görüşü genelde din eğitiminde benimsenen bir usuldür (Turan ve Nazıroğlu, 2020; Tongar, 2018; Köylü ve Altaş, 2019; Doğan ve Ege, 2017).

Çocuk, ahlaka aykırı içeriği olan kitap ve yayınlardan uzak tutulmalıdır. Çünkü bu tür yayınlar çocuğun kalbine ve ruhuna bozukluk tohumları eker. Bu, günümüz için de geçerli bir ilkedir. Hemen her toplumun kültüründe ve yasalarında, çocukların fiziksel ve ruhsal sağlığını bozduğu gerekçesiyle, çocukları bu tür yayınlardan uzak tutmayı ve korumayı amaçlayan kurallar bulunmaktadır (Akyüz, 2018; ASPB, 2017; Uzun, 2014).

Güzel davranışlarının ardından çocuk ödüllendirilmelidir. Aile, memnuniyetini çocuğa açıkça göstermeli, onu başkalarının önünde sevmeli, övmeli ve ona hediyeler vermelidir. Gazali' nin bu görüşü için de dördüncü maddede dile getirilen eleştiriler geçerlidir. Ayrıca, eğitimde ödülün en az ceza kadar zararlı sonuçlar doğurduğu yönünde güncel araştırmalar (Pedagoji Derneği, 2013) da mevcuttur.

Aile, çocuğun yanlış davranışlarını düzeltmeye çalışmalıdır. Bunun için önce yumuşak sözlerle onu ikna etmeye çalışmalı ve davranışının alternatifleri olabileceğini ona göstermelidir. Şayet çocuk bu yolla ikna olmuyorsa onun haline uygun bir sertlik takınılmalı ve onun israrına karşı ailesinin de bu durumun değişmesi konusunda 1srarcı olduğu ona gösterilmelidir. Gazali'nin bu yönteminin (sertliğin şiddet içermeyen tutum olduğu varsayılarak) modern pedagojik yöntemlerle uyuştuğunu söylemek gerekir (Pedagoji Derneği, 2013). Önce yumuşak sözlerle ikna etmeye çalışmak, bunun yetmediği durumda şiddet içermeyen 1srar günümüzde de çocuk eğitiminde kullanılmaktadır (Duygulu, 2010).

Aile, çocuğu iyiliğe yöneltip kötülükten uzaklaştırırken onun psikolojik özelliklerini dikkate almalıdır. Çünkü psikolojik özellikler ruhun kapılarıdır. Bu kapıları bulup oradan içeri giremeyenler, çocuğun ruhuna ulaşıp onu etkileyemezler. Dolayısıyla onu iyiliğe yöneltemezler ya da kötülükten uzaklaştıramazlar. Bu durum, birçok ilişki biçiminde geçerlidir. Doktor hastasını tanımadan ona uygun ilaç veremez ya da eğitimci öğrencisini tanımadan ona uygun bir eğitim yapamaz. Gazali'ye göre ilahi metot da böyledir. Allah kullarını Kur'ân'da bazen teșvikle, bazen korkuyla, bazen ümitle terbiye etmektedir. Gazali'nin bu açıklamalarının da günümüz modern psikolojik yöntemleriyle ve eğitsel yaklaşımlarıyla uyumlu olduğunu söylemek gerekir (Nair, 2018; Iş1k, 2018; Uzun, 2017; Yüksel, 2017; Pedagoji Derneği, 2013; Duygulu, 2010; El-Affani, 2007).

Çocuk, mümkün olduğunca sade ve zorlu bir hayat tarzına alıştırılmalıdır. Ailesi onu yumuşak yatakta yatırmamalı ve ipek elbiseler giydirmemelidir. Çünkü rahata alışmak çocuğu hem bedensel hem de zihinsel olarak zayıf ve dayanıksız yapar. Rahatlığın bir sonucu olarak bu tür çocuklar genelde şişman olurlar. Bu da istenmeyen bir durumdur. Modern toplumların en önemli sorunlarında biri de obezite ve ona bağlı ortaya çıkan sağlık sorunlarıdır. Günümüzde gelişmiş devletler bu tür sorunlar için çok ciddi bütçeler ayırmaktadır (SB, 2020; NTV, 2019; Medimagazin, 2019). Gazali'nin bu görüşü, aynı zamanda İbn Haldun'un 'devletlerin rahata ulaşmalarının aynı zamanda onlar açısından bozulmanın ve yıkılmanın başlangıcını oluşturduğu yönündeki görüşleriyle' (İbn Haldun, 2009) de paralellik arz etmektedir.

Aile çocuğuna mütevazı olmayı, gösteriş yapmamayı, paylaşımcı olmayı, arkadaşlarıyla iyi geçinmeyi ve onlardan bir şeyler istememeyi öğretmelidir. Bu öğretim içerikleri günümüzde değerler eğitimi adı altında çocuklara kazandırılmak istenen hedef içerikler (Özcan, 2019; Oktay, 2018; Cihan, 2014) ile örtüşmektedir. 
Aile, çocuklarına büyüklere karşı saygılı olmayı öğretmelidir. Odaya girdiklerinde ayağa kalkmak, konuşurken onları dinlemek ve onlara hizmet etmek yaşlılara gösterilebilecek saygı davranışlarındandır. Yaşlılara saygı, farklı uygulama ve tutumları barındırmakla birlikte hemen her kültürde benimsenmiş bir eğitim içeriğidir (Tutal, 2018).

Kız çocuklarına, henüz sorumluluk çağına gelmemiş olsalar bile İslami usullere göre giyinme alışkanlığı kazandırılmalıdır. Gazali, din âlimi hassasiyetiyle dile getirdiği bu görüşünü alışkanlık kavramı üzerine inşa etmiştir. Aslında ona göre çocukların giyinme davranışlarıyla ilgili bir problem yoktur; onun problem olarak algıladığı, İslam'a uygun olarak giyinme alışkanlığının çocuk yaşlarda kazanılıp kazanılamayacağı ile ilgilidir.

Aile, yedi yaşına geldikten sonra çocuklarına namaz kılmayı öğretmenli ve Ramazan Ayında birkaç gün de olsa oruç tutmasını tavsiye etmelidir. Bu içeriğin İslam peygamberinin öğütleri doğrultusunda hazırlandığı anlaşılmaktadır. Zira Hz. Muhammed'in çocuk yedi yaşına geldiğinde ona namazın öğretilmesinin gerekliliği hakkında hadisi vardır (Ebu Davud, Salat: 26; Tirmizi, Salat: 299).

Sadaka vermek gibi hayırlı işler çocuğa yaptırılmalı ve bu suretle çocuk bu tür işlere alıştırılmalıdır. İyilik doğru olarak yapılınca büyüyen, öğrenilen ve pekişen bir davranıştır. Bu anlamda Gazali’nin ailelere, çocuklarına iyiliğin nasıl yapılacağını öğretmeleri yönünde sorumluluk yüklemesi takdire şayan bir durumdur.

Meşru olmayan işlerden nefret etmesini ve iğrenmesini sağlamak da ailenin çocuğa öğretmesi gerek hallerdendir. Gazali'nin bu maddede söyledikleri çok açık değildir. Zira gayrı meşru işler ile neyi kastettiği belli değildir. Ayrıca ailenin bunu nasıl yapması gerektiği ile ilgili de açıklama yapmamıştır.

Aile çocuğa bir yandan çalışmayı sevdirmeli, diğer yandan da mal hırsının kalbine yerleşmesine mâni olmalıdır. Çalışmak ne kadar iyi bir şeyse, para hırsı da o kadar kötü bir şeydir. Müslüman için para, çalışmanın gayesi haline gelmemelidir. Çalışmanın gayesi, dünyayı imar etmek suretiyle Allah'ın rızasını kazanmak ve başkalarına muhtaç olmamaktır. Gazali'nin çalışma ile para kazanma arasında kurduğu bu hassas ilgi İslam inanciyla örtüşmektedir (Arslan, Turgut, Hasanov ve Sezer, 2018). O, diğer konularda olduğu gibi bu konuda da çocukların İslam ilkelerine uygun yetiştirilmesini hedeflemiştir.

'Nasıl olsa bir gün doğru yolu bulurlar zannıla çocukları ve gençleri hatalarıyla baş başa bırakmak' onlara yazık etmektir (Gazali, 2004). Çünkü yanlışa alışan çocukların daha sonra kendi başlarına o yanlıştan kurtulmaları ve o konudaki doğruya ulaşmaları o kadar da kolay değildir. Bazen de kişi yanlışını fark ettiğinde artık iş işten geçmiş olur. Bu durumda yanlışı fark etmiş olmanın anlamı olmaz.

Gazali, çocukları toplumun yapı taşları ve geleceğin büyükleri olarak gördüğü için onun eğitim anlayışı aynı zamanda ahlak eğitimidir. $\mathrm{O}$, ahlaklı bir nesil yetiştirme gayesindedir. $\mathrm{Bu}$ nedenle çocuk eğitiminde yalan söylemenin zararları, kötü huylardan sakındırma, büyüklere saygı, sadaka ve yardımlaşmanın öğretilmesi gibi birçok sosyal konu üzerinde önemle durmuştur (Durakoğlu, 2014).

Gazali, "Ey inananlar! Kendinizi ve ailenizi, yakıtı insanlar ve taşlar olan ateşten koruyun. Onun başında, acımasız, güçlü, Allah'ın kendilerine buyurduğuna karşı gelmeyen ve emredildiklerini yapan melekler vardır." (Kur'ân, 66/6) mealindeki ayetten hareketle çocuk eğitiminde birinci derecedeki sorumluluğun ailede olduğunu söylemektedir. Ona göre aile, çocuğunu İslami öğretilere göre yetiştirerek cehennemden korumalıdır (Gazali, 2015).

Ailenin bu sorumluluğu içerisinde çocuğun kişiliğini şekillendirmek, onu ruhsal ve bedensel açıdan eğitmek, onu içinde yaşadığı toplumun sosyal koşullarına hazırlamak ve çocuğa yeterli dini eğitim vermek de bulunmaktadır (Bayrakdar, 2004). 
Gazali, Kimya - yı Saadet'te (2015) de çocuk eğitimi ile ilgili müstakil bir bölüm ayırmıştır. Bu bölümdeki görüşlerin çoğu Ihy $a$ 'daki görüşleriyle örtüşmektedir. Bununla birlikte farklı bazı hususlar da bulunmaktadır. Örneğin İhya'da çocuklara Kur'ân okumayı öğretmenin gerekliliğinden söz etmiştir. Kimya'da buna, kıraat ilmi, siyer ilmi ve sahabenin hayat hikâyelerinin öğretilmesini eklemiştir (Gazali, 2015).

Gazali, çocuk eğitiminde şiir konusuna karşı ilişskin ilginç bir tutum takınmıştır. Onun düşüncesine göre (2015), çocuklar şiirden uzak tutulmalıdır. Çünkü şiirde, aşktan ve güzellerden bahsedildiği için bu, çocukların kalbine fesat tohumları ekebilir. Gazali bu tutumunda o kadar katıdır ki, ona göre çocukları, 'şiirle uğraşmak insan tabiatına incelik katar' diyen hocalardan da korumak gerekir. Çünkü bu tür hocalar çocukları olumsuz etkileyebilirler.

Gazali'nin İhya'da on sekiz madde halinde dile getirdiği çocuk eğitiminin konu içerikleri, aynı zamanda çocuk eğitiminde uyulması gereken ilke ve yöntemleri de kapsamaktadır. Bu maddeler analiz edildiğinde şu ilke ve yöntemlere ulaşılmaktadır (Gazali, 2004):

$\checkmark$ Örneklendirme

$\checkmark$ Anlatma

$\checkmark$ Yaparak - yaşayarak öğretme

$\checkmark$ Övme

$\checkmark$ Sosyalleştirme

$\checkmark$ Zararlı yayınlardan koruma

$\checkmark$ Ödüllendirme

$\checkmark$ İkna etme - alternatif önerme, sevdirme - korkutma

$\checkmark$ Yumuşak - sert davranma

$\checkmark$ Doğruda israr etme

$\checkmark$ Çocuğa görelilik

$\checkmark$ Kendine yetmeyi öğretme

$\checkmark$ Saygili olma

$\checkmark$ Alıştırma

Bunlar dışında, Gazali'nin eğitim anlayışı bilinenden bilinmeyene, tedricilik (kademeli olarak), somuttan soyuta, riyazet (az olanla yetinme), ödül - ceza, sabır gibi ilke ve yöntemleri de barındırmaktadır (Çelikel, 2006).

Bir başka çalışmada, Gazali açısından eğitim öğretimin ilkeleri, kritik dönem ilkesi, hürriyet ilkesi, rehberlik ilkesi, tedricilik ilkesi, ferdi farklllkklar ilkesi, aktivite ilkesi, denge ilkesi ve hidayet ilkesi olarak belirlenmiştir (Oruç, 2009)

Gazali'nin çocuk eğitimine bu denli önem vermesi, çocukluk çağında yapılan eğitimin daha kalıcı olduğuna ilişkin inancından kaynaklanmaktadır. O, küçükken yapılan öğretimi, 'taş üzerine yazı yazmaya' benzetmektedir (Gazali, Trh.). Çocukluk dönemi ahlaki karakterin oluşmaya başladığı, insan ilişkilerine temel teşkil eden duyguların oluştuğu bir dönemdir. Çocukluk dönemi eğitiminde yapılan hataların telafisi ise çok güçtür (Çamdibi, 2014). Bu sebeple, çocukluk çağındaki eğitime hak ettiği önem verilmelidir.

\section{İbn Haldun’a Göre Çocuk Eğitiminin Konu İçerikleri ve İlkeleri}

İbn Haldun dönemsel olarak Gazali'den ortalama üç yüz yıl sonra yaşamış bir düşünürdür. Yaşadıkları bölgeler de kısmen birbirinden farklıdır. Gazali hayatının büyük çoğunluğunu Tus (Meşhed), Bağdat ve Şam üçgeninde geçirmiş̧tir. İbn Haldun ise Afrika'nın kuzeyinde batı - doğu hattında Tunus ile Mısır arasındaki coğrafyada yaşamıştır. Ayrıca tebası oldukları devletler ve hükümdarlar da birbirlerinden farklıdır. Buna karşı1ık aldıkları ve tabi oldukları eğitim sistemlerinin benzer olduğu söylenebilir. İbn Haldun da Gazali gibi önce aile büyüklerinden, sonra yakınlardaki alimlerden ve medreselerden ilim tahsil etmiştir (İbn Haldun, 2011). 
Yaşadıkları zaman itibariyle her iki düşünürün büyüdükleri eğitim ikliminin medrese tarzı eğitim içinde kaldığını belirtmek gerekir. Esasen Orta Çağ, İslam Dünyası açısından bir medreseler çağıdır. Orta Çağ'ın hâkim eğitim kurumu olan medreseler sadece talebelere İslami ilimleri öğretmekler kalmıyor aynı zamanda hükümdarların sahip olduğu geniş coğrafyalardaki siyasal iktidarlarının devamı amacına da hizmet ediyorlardır (Makdisi, 2019, 2018). Bu yüzden Gazali ve İbn Haldun aldıkları medrese eğitimlerinin sonucunda sadece din alimi olarak kalamamış aynı zamanda dönemin siyasal meseleleriyle de ilgilenmek zorunda kalmışlardır (Gazali, 2020; İbn Haldun, 2011).

İbn Haldun da Gazali gibi eğitim öğretime önem veren bir düşünürdür. Hatta İbn Haldun, altı kitaptan oluşan Mukaddime'sinin altıncı kitabını İlimler, Öğretim ve Usulleri başlı̆̆ eğitimle ilgili konulara hasretmiştir. Bu kitapta da Talim ve Takrir Usulü İtibariyle İlimlerde Takip Edilmesi Doğru Olan Tarz ile Çocukların Eğitimi ve Bu Hususta İslam Beldelerinde Takip Edilen Muhtelif Usuller gibi başlıklarla çocuk eğitiminin içerik ve ilkelerini ele aldığı özel alt bölümler oluşturmuştur.

İnsan ontolojik açıdan akıl ve fikir özellikleriyle donatılmış olmasına karşılık, epistemolojik bağlamda, yaratıldığı ilk andan itibaren neredeyse tüm bilgi türlerinden mahrumdur. Bu birleşim onu aynı zamanda eğitilebilir bir varlık kılmıştır. İbn Haldun eğitim anlayışını bu temel üzerine inşa etmiştir (Oruç, 2010).

İnsan zatı (yaratılışı) itibariyle cahil, kesb (kazanma) itibariyle âlimdir (İbn Haldun, 2009). Diğer bir deyişle, bilgisiz olarak dünyaya gelen insanın gayret ederek âlim seviyesinde bilgili olması mümkündür. Bilgili olmanın yolu da eğitimden geçmektedir. Bu nedenle eğitim, ciddiyetle üzerinde durulması gereken bir iştir.

İnsan her ne kadar yaratılışı itibariyle boş bir zihinle doğmuş olsa da Allah onu, bu boş zihnini doldurabilecek kabiliyetlerle ve potansiyelle yaratmıştır. İnsanın bu yeteneği, düşünebilmesi ve fikir üretebilmesidir. Allah, bu yolla insanları hayvanlardan ayırmış ve ona mükemmelliğe ulaşabilecek bir anahtar vermiştir (İbn Haldun, 2009). Aklının insanı kemale ulaştırması, eğitilmesine ve bu yolla geliştirilmesine bağlıdır.

İlimler ve eğitim umranın ruhunda var olan doğal niteliklerdir. Zira insan, düşünme yeteneği sayesinde yaşamını sürdürecek ve geçimini sağlayacak işler üretir. Yine bu sayede toplumsal bir yaşama dahil olur, başkalarıyla yardımlaşır ve dinini öğrenir. Toplumsal yaşam insan için beslenme, barınma, üreme gibi temel ihtiyaçlarının yanında başka ihtiyaçlar da türetir. Bu yeni ihtiyaçlar toplumda yeni ilim dallarının doğmasını ve öğrenilmesini zorunlu kılar. İbn Haldun (2009: 766) bu durumu şöyle özetlemiştir: "Böylece aşikâr bir surette ortaya çıkmıştır ki, ilim ve talim beşer için doğal bir zorunluluktur."

Eğitim ve öğretim, sanat kabilinden (kendi has konuları ve yöntemleri olan) bir iştir. Dolayısıyla teknik bir konudur. Ona göre eğitim - öğretimin sanat sayılmasının delili, kendine ait özel bir terminolojisinin olmasıdır. Meşhur hocaların her birinin kendine ait usulü ve sstılahı vardır. $\mathrm{Bu}$ istılahlar öğretimde kullanılan sanatlardan ibarettir. Genel manada ilim tektir; ancak 1stılahlar çeşit çeşittir (İbn Haldun, 2009).

Öğrenciler, ilim denizinden kendilerine uygun buldukları ilimleri öğrenmek için tercihte bulunabilirler. $\mathrm{Bu}$ alanda onlara özgürlük tanımak gerekir. Ancak, öğrencilerin öğrenmek istedikleri alanı kendilerinin tercih etmiş olması o alanda başarılı olacakları anlamına gelmez. Çünkü her ilim dalının gerekli kıldığı bazı yeterlilikler vardır. Öğrenciler arasında da bu yeterlilikler bakımından farklar vardır. Dolayısıyla öğrencinin yeterliliklerinin tespiti ve uygun ilim dalına yönlendirilmesi konusunda ilim ehli üstatların görüşlerine başvurmak gereklidir (İbn Haldun, 2009). 
İbn Haldun çevresinde olup bitenleri olgusal olarak gözlemleyen ve düşüncelerini bunlar üzerine kurgulayan iyi bir bilim adamıdır. Haliyle yaşadığı ve gezdiği coğrafyalardaki eğitim konusunu da gözlemlemiştir. O, bu gözlemleri esnasında, İslam diyarlarındaki çocuk eğitimin miğfer konusunu teşkil eden hususun Kur'ân eğitimi olduğunu gözlemlemiştir. O, bunun sebebi olarak, imanın kalplerde kökleşmesi için öncelikle Kur'ân'ın öğrenilmesine ihtiyaç duyulmasını göstermiştir. Ayrıca bu eğitimin çocukluk yaşlarda yapılmasının kalıcı olmasının ön koşulu olarak algılandığını belirtmiştir (İbn Haldun, 2009).

İbn Haldun, Kur'ân öğretimi konusunda yaşadığı ve dolaştığı bazı bölgelerdeki usul ve yöntemleri kıyaslamıştır. Buna göre (İbn Haldun, 2009):

Mağrip (Fas - Yemen bölgesi) halkı Kur'ân'ın ezberletilmesi (hafızlık) ve güzel yazıyla yazılmasına (hat) önem vermektedirler. Onlar, talebe Kur'ân tilavetinde maharet kazanana kadar ya da maharet kazanmadan talebeliği bırakana kadar bu yol üzerinde israr ederler. Onlar Kur'ân eğitiminin yanına diğer konuları katmazlar. Bu nedenle Mağrip eğitim sisteminde ne hadis ne fikıh ne şiir ne de Arapça yer almaktadır.

Endülüslüler Kur'ân eğitiminde kıraat ve kitabet (okuma - yazma) ilmini önemserler ve bunu başka ilimlerle karıştırmazlar. Ancak onlar çocuklarına bunun yanında şiir rivayetini ve tahririni, Arap dilini ve hüsn-ü hat (güzel yazı) sanatını öğretirler. Bu eğitim ergenlik çağına kadar devam eder. İbn Haldun'a göre bu Endülüs eğitiminin olumlu tarafıdır. Ancak onların eğitimde eksik bıraktıkları hususlar da vardır. Endülüs eğitiminde talim senedi ve eğitimin dayandığı bir gelenek mevcut değildir. Diğer bir deyiş̧le, Endülüs eğitimi, başarılı hocaların elinde iyi yürütülmektedir; ancak bu, bir sistemin ve geleneğin ürünü değil, bireysel çabaların sonucudur.

İfrikiye (Tunus - Cezayir bölgesi) halkı Kur'ân eğitimine önem vermekle birlikte, çoğunlukla bu eğitimi hadis eğitimiyle karıştırmış ve harmanlamış durumdadırlar. Onlar Kur'ân'ın ezberletilmesi dışında rivayete, kıraate ve yazıya önem atfetmişlerdir. İfrikiyelilerin eğitim tarzı, Mağrip tarikinden ziyade, Endülüslerin yoluna daha çok benzemektedir.

İbn Haldun, Doğu ahalisinin Kur'ân eğitimi konusunda muhtelif usuller benimsediğini; ancak, Kur'ân'ın yanında neleri öğrettiklerini tam olarak bilmediğini belirtmiştir. Bununla birlikte, duyduklarından hareketle, Kur'ân'ın yanında çeşitli ilmi kitaplanı tedris ettiklerini, dini esasların öğretilmesine önem verdiklerini ve bunları güzel yazı eğitimi ile karıştırmadıklarını, güzel yazıyı küçük çocukların eğitiminde kullanmayıp, yalnızca buna karşı yeteneği olanlara ilerleyen dönemlerde öğrettiklerinden söz etmiştir.

O, özellikle Mağrip ve İfrikiye halkının Kur'ân eğitimini önemsemelerine karşılık Arapça öğretmeyi önemsememelerini eleştirmektedir. Bu durum, özellikle Arap olmayanlar açısından büyük bir eksikliktir. Çünkü onlar, Arapçayı ana dilleri olarak konuşmadıkları için bu konuda bir yeterlilikleri yoktur. Arapçayı tam olarak anlamadan Kur'ân'1 tam olarak anlamaları da mümkün değildir. İfrikiyeliler bu konuda Mağriplilerden daha iyi seviyede olmakla birlikte, yine de belagat seviyesinin gerisindedirler (İbn Haldun, 2009).

İbn Haldun eğitim konusunda Mağrip ve İfrikiye halkını eleştirmesine karşılık Endülüs halkını da övmüştür. Ona göre Endülüslülerin eğitimde her türlü ilim dalına yer vermeleri, inşa ve tahrir üzerinde fazlaca durmaları, çocuklara çok erken yaşlarından itibaren Arapça öğretmeleri takdire şayandır. Onların Arapçaya bu kadar önem vermeleri çocukluk dönemindeki eğitimden sonraki eğitimlerinde öğrencilerin edebiyat alanında gelişmelerine yol açmıştır. Bununla birlikte Endülüslüler, diğer ilim dallarıyla çok ilgilendikleri için Kur'ân okumada diğer topluluklardan geri kalmışlardır (İbn Haldun, 2009).

İbn Haldun, bu son paragraftaki görüşlerini serimlerken eğitim tarihi açısından önemli iki kavramı eğitim terminolojisine ve literatürüne kazandırmış görünmektedir: ilkögretim ve ikinci ögretim (İbn Haldun, 2009). İlköğretim ile sabilik çă̆ındaki çocukların eğitimini kastetmektedir. 
Günümüz kavramlarıyla bu dönem eğitimi, okul öncesi eğitimden buluğ çağına girilen, yani, yaklaşık lise dolaylarına kadar yapılan eğitim kast edilmektedir. İkinci öğretim ile buluğ çağına girmiş geçlerin ve yetişkinlerin daha ileri düzeydeki eğitimleri kast edilmektedir.

İbn Haldun (2009: 988), Kadı Ebu Bekir İbnü’l Arabi'nin Rıhle isimli kitabında çocukların eğitimi konusunda anlattıkları şöyle nakletmiştir:

Şiir, Arap divanıdır. Dilin bozulmuş olması, eğitimde șiir ve Arapçanın öncelikli olarak öğretilmesini zaruri kılmıştır. Bundan sonra hesap eğitimine geçerek, temel kurallarını belleyene kadar bu konuda alıştırma yaparlar. Sonra Kur'ân dersine dahil olurlar. Çünkü bu girizgâhtan sonra Kur’ân ilimleri talebe için daha kolay bir hal alır... $\mathrm{Ne}$ acı ve derin bir gaflettir ki beldemiz halkı daha işin başında sabi çocukları Allah'ın kitabını öğrenme mecburiyetiyle karşı karşıya getirmektedirler. Zavallı masumlar anlamadıkları bir metni okumakta ve kendileri için daha önemli birtakım şeyler varken böyle bir işte didinip durmaktadırlar.

İbn Haldun, İbn Arabi'nin eğitimin sonraki aşamalarında talebelerin Kur'ân'dan sonra dinin esaslarını, fıkıh usulünü, cedeli, hadisi öğrenmeleri gerektiğini belirterek zekâsı çok yüksek olanlar istisna_bu paket öğretim programının bozulmasına karşı çıkmaktadır (İंbn Haldun, 2009). Daha önce de belirtildiği üzere, İbn Haldun ilmin tek olduğunu düşünmektedir. Başka bir ifadeyle, ona göre âlim olmak için belli ilimlerin tamamında yetkin olmak gerekir. Ancak ilim öğrenme usulleri ve yolları açısından farklılıklar olabilmektedir.

O, Kadı Ebu Bekir'in ilim konusunda söylediklerini benimsemektedir. Bunu, şu sözlerinden çıkarmak mümkündür (İbn Haldun, 2009: 989): “Allah rahmet etsin, Kadı Ebu Bekir'in tavsiyesi işte budur. Vallahi bu, güzel bir usuldür.” İbn Haldun bunları söyleyerek gönlünden geçen eğitim içeriğini ve usulünün bu olduğunu belirtmiş; ancak, geleneklerin bu usule izin vermeyeceğini de eklemiştir. Çünkü ona göre insanlar, daha sevap olduğunu düşündükleri için, Kur'ân eğitimini öncelemekten vazgeçmeyeceklerdir. Bunun bir diğer nedeni de ahalinin, talebelerin uzun süre eğitim almayı istemeyeceklerini düşündükleri için onlara en başından Kur'ân'ı öğretme yönündeki tercihleridir. Onlar böylece, çocukların eğitimi kesilirse eksik kalan kısmın Kur'ân olmayacağını zannetmektedirler. İbn Haldun'a göre, şayet ahalide talebelerin ilmi sürekli talep edecekleri kanaati oluşsaydı, Kadı Ebu Bekir'in dile getirdiği usul, Mağrip ve Meşrık ahalisinin uygulayageldikleri usulden çok daha fazla tercihe şayan olurdur.

Ona göre (2009), ilimlerin talebelere azar azar ve tedrici bir usulle aktarılması en doğru yöntemdir. Hoca, önce konunun bir kısmını anlatmalı, o kısım anlaşıldıktan sonra devamı niteliğindeki konulara geçilmelidir. Bu yöntem hem zeki öğrencilere hem de zekâsı o kadar parlak olmayan öğrencilere en fazla faydayı sağlar. Çünkü bu usulde öğrencinin düşünme kapasitesi belli bir konu odağında toplanmaktadır.

Her öğrencinin zekâ seviyesi ve anlama kapasitesi birbirinden farklı olabilir. Hocalar bu hususu dikkate almalıdır. Kısa anlatım ve özetlerle başlayan eğitim daha sonra şerh ve izah gibi ayrıntılama düzeyine geçmelidir.

Bir ilmin öğretiminde üç aşamalı bir yöntem benimsenmelidir. Birinci aşamada, konu kısa metinler ve özetlerle anlatılmalıdır. İkinci aşamada konu izah ve şerhlerle biraz daha ayrıntılı ele alınmalıdır. Üçüncü aşamada ise o ilimle ilgili tartışmalı ve muğlak meseleler aydınlatılmalıdır. Faydalı ve tesirli talim tarzı bu şekilde üç tekrarla hâsıl olmaktadır. Ancak öğrencilerin kapasitesi yüksekse daha az tekrarla da istenilen sonuç elde edilebilir (İbn Haldun, 2009).

İbn Haldun kendi çağında, öğretim ve takrir (ifade) yöntemlerini bilmeyen çok sayıda hocanın varlığını müşahede ettiğinden söz etmekte ve bu durumu eleştirmektedir. Bu hocalar, talebenin hazır bulunuşluk düzeyini dikkate almadan onları muğlak birtakım meselelerle karşı karşıya getirmekte ve eğitim işini gereksiz yere zorlaştırmaktadırlar. Eğitimin sonunda talebenin 
yerine getirmesi gereken sorumlulukları daha başta istemektedirler. $\mathrm{Bu}$ durum talebelerin zihinlerini bulandırmaktan başka bir işe yaramamaktadır (İbn Haldun, 2009).

Talebeler, eğitimin başında karmaşık meseleleri anlamaktan acizdirler. Bu yöntemde ısrar edilecek olunursa, talebeler konuyu anlamayacakları gibi ondan uzaklaşacaklardır. Talebenin anlamasına en elverişli yöntem konuyu peyder pey ve tedrici olarak belletmeye çalışmaktır. Aksi takdirde, talebenin zihninde bıkkınlık oluşacak, öğrenmeye karşı ihmalkâr ve tembel davranacak ve en sonunda da o ilim dalından kopup gidecektir (İbn Haldun, 2009).

Muallime yakışan ister eğitimin başında ister sonunda (mübtedi - müntehi) olsun talebeyi, ona okuttuğu ders ya da kitap konusunda sınırlarını, kabiliyetini ve kapasitesini aşacak şekilde sorumlu tutmamaktır. Muallime düşen bir başka vazife de okuttuğu kitabı veya dersi başka kitap veya derslerle karıştırmamaktır. Böylece muallim, öğretilecek mevzunun dışına çıkmamış ve müfredatı karıştırmamış olur (İbn Haldun, 2009).

Hocalar, ders meclislerini ayırarak ve dersler arasında kesintiler meydana getirerek talebenin tahsil süresini uzatmamalıdırlar. Diğer bir deyişle farklı kademedeki dersler arasına tatil mahiyetinde uzun müddetlerin konması, birbirinin devamı niteliğindeki dersler arasında kopukluk oluşturacaktır. Bu durum, hem derslerin anlaşılmasını ve tamamlanmasını zorlaştıracak, hem de öğrencinin eğitim süresini gereksiz yere uzatacaktır (İbn Haldun, 2009).

İbn Haldun'un üzerinde önemle durduğu bir başka husus öğrenilenlerin meleke haline gelmesi yani tam ögrenme olayıdır. İlimdeki meleke, talim ve tedrisle ilgili faaliyetlerin ve tekrarların peş peşe olmasıyla kazanılır. Bir konu hakkında talebede meleke hâsıl olmuşsa, talebe o konudaki her şeye hâkim demektir. Bunun için de o ilmin başıyla sonu arasındaki irtibat sürekli olmalı, arada kopukluk olmamalıdır.

İbn Haldun bu bölümün sonunda öğrenme ile mantık arasındaki ilişkiyi irdelemiştir. Ona göre (2009) insanın idrak edebilmesinin vasıtası dil ve mantık değil, insanın doğuştan getirdiği fikir (düşünme) yeteneğidir. Ancak insan, tümüyle, kendisine bu yeteneği bahşeden yüce Allah'a dayanmalıdır. Mantık ise, düşünme faaliyetini tasvir eden bir ilim dalından başka bir şey değildir. Bu nedenle mantık, çoğunlukla fikir ile aynı paralellikte bulunur.

\section{Sonuç}

İslam düşünürleri eğitim ve öğretim ile ilgili konuları ele alırken genellikle ilke, yöntem ve konuları çok ayırmamıştır. Bu durum, Gazali ve İbn Haldun için de geçerlidir. Özellikle Gazali'de bu durum çok daha belirgindir. Konu ve öğretim yöntemleri iç içe girmiş, karışmış durumdadır. Bazen konu ile kast edilen yöntem, bazen usul ile kast edilen eğitim içeriğidir.

Yaşadıkları dönem itibariyle ve din âlimi konumları gereği her iki düşünür için de çocuk eğitiminin ana konusu Kur'ân'dır. Gazali Kur'ân eğitimine Kıraat, Siyer (Peygamberin Hayatı) ve Sahabelerin Hayatları gibi konuları eklemiştir. İbn Haldun Kur'ân eğitimi ile kıraati aynı görmektedir. O, bunların yanına Güzel Yazı, Arapça, Şiir, Hesap, Fıkıh, Cedel gibi konuların eklenmesini gerekli görmüştür.

İncelenen düşünürlerin her ikisi de din âlimi olmasına karşı1lı Gazali'deki vurgular daha dini içeriklidir. İbn Haldun ise olaya daha bilimsel yaklaşım sergilemiş, gözlemlerinden ve olgulardan hareket etmiştir. Ona göre eğitim, umrandaki tabii hallerden biridir.

Öğrenme yöntem ve teknikleri açısından her iki düşünürün görüşleri arasında çeşitli benzerlikler vardır. Örneğin aşamalı öğretim yapılması (tedricilik), kolaydan zora gidilmesi, konuların bir üstat tarafından aktarılması, öğrencilerdeki bireysel farkların dikkate alınması gibi birçok yöntem üzerinde mutabıktırlar.

Buna karşılık Gazali ve İbn Haldun'un eğitim öğretim konusunda farklı düşündükleri alanlar da mevcuttur. Örneğin Gazali, tüm olumlu yollar denenmesine ve bu yöntemlerde 1srar 
edilmesine karşılık öğrencinin yanlışta devam etmesi durumunda sertliğe başvurulabileceğini belirtmektedir. İbn Haldun ise eğitimde şiddete ve sertliğe tamamen karşı bir duruş sergilemiştir. Yine, Gazali'nin çocuk eğitiminde aileyi ve evi ön plana çıkarmasına karşılık, İbn Haldun eğitimde daha çok medrese ve okulları ön plana almıştır. Düşünürlerin ayrıldığı bir nokta da şiir konusudur. Gazali, şiir öğretimine tamamen karşıyken, İbn Haldun şiiri, çocuklara mutlaka öğretilmesi gereken bir alan olarak görmektedir.

Çocuk eğitimi konusunda Gazali daha gelenekçi bir görüntü sergilerken İbn Haldun'un daha yenilikçi bir profil çizdiği söylenebilir. İbn Haldun'un eğitim öğretim alanına bazı ilkler ve yenilikler getirmesi bunun göstergesidir. Örneğin, ilk defa birinci ögretim ve ikinci öğretim kavramlarını kullanarak eğitimdeki kademelere dikkat çekmiştir. Yine bir ilim dalında meleke kazanma, "tam öğrenme"ye karşılık kullanılan önemli bir kavramdır. Ayrıca, çocuklara Kur'ân eğitiminden önce temel dilbilgisi ve hesap kurallarının öğretilmesi gerektiğini söylemesi zamanı açısından radikal derecede yenilikçi olarak ifade edilebilecek bir tekliftir.

İbn Haldun talebeyi ilimden soğutacak hatalar üzerinde 1srarla durmuştur. Ona göre âlimlerin en çok tekrarladıkları hata, talebeye kapasitesine uygun olmayan bir müfredat uygulamak ve onları gereksiz sorumluluk altına sokmaktır ki, bunun sonucunda talebe ilimden ve ögrenmeden soğuyabilir. Talebeleri ilimden soğutmamak her iki düşünürün de önemsedikleri ortak bir konudur.

Çocuk eğitiminin konu içerik ve ilkeleri bağlamında Gazali'nin ve İbn Haldun'un düşüncelerinin karşılaştı̆̆ 1 bu çalışmada, her iki düşünürün benzer ve farklı görüşlerinin olduğu tespit edilmiştir.

\section{Kaynakça}

Acar, E. (2017). Bağırıp çağırmadan çocuk eğitimi. Yediveren Yayınları

Adıvar, A. A. (1940). "İbn Haldun” maddesi. İslam Ansiklopedisi. Cilt: 5. Millı̂ Eğitim Bakanlığı Yayınlar1

Aile Sosyal Politikalar Bakanlığı [ASPB] (2017). Türkiye'de çocuklara yönelik koruyucu ve önleyici politikaları değerlendirme çalıştayı raporu. Editörler: Esra Kömür Ali Güngör, Hazırlayan: Olgun Gündüz. $\quad$ ASPB Yayınları https://www.ailevecalisma.gov.tr/media/2498/turkiye-de-cocuklara-yonelik-koruyucu-veonleyici-politikalari-degerlendirme-calistayi-raporu.pdf. https://doi.org/10.29228/turkishstudies.22526

Akyüz, E. (2018). Çocuk hukuku: Çocukların hakları ve korunması (6. Baskı). Pegem Akademi

Arslan, A., Turgut, B., Hasanov, B. ve Sezer, M. (2018). Emeğin değeri: Din ve emek ilişkisi. Zonguldak: Bülent Ecevit Üniversitesi Yayınları, No: 27. Web: http://isamveri.org/pdfdrg/G00329/2018/2018_TURGUTB.pdf. https://doi.org/10.5152/hsp.2019.517803

Aydınlı, Y. (2015). Gazali muhafazakâr ve modern. Emin Yayınları

Bayrakdar, M. (2004). İslam düşüncesi yazıları: Gazali ve çocuk eğitimi. Çeviren: Mehmet Vural. Elis Yayınları

Bolay, S. H (2005). Aristo metafiziği ile Gazali metafiziğinin karşılaştırılması. MEB Yayınları

Choudry, M. A. and Silvia, B. (2008). A critique of Ibn Khaldun's causality concept. JKAU: Islamic Economy, 21(1), 49-70. http://www.kau.edu.sa/Files/320/Researches/51087_21221.pdf 
Cihan, N. (2014). Okullarda değerler eğitimi ve Türkiye'deki uygulamaya bir bakış. Turkish Studies - International Periodical For The Languages, Literature and History of Turkish or Turkic, 9(2), Winter 2014, 429-436, https://doi.org/10.7827/turkishstudies.6402

Çağrıcı, M. (1996). “Gazzali” TDV İslam Ansiklopedisi, Cilt: 13, 489-505. $\mathrm{http} / / / \mathrm{www}$. islamansiklopedisi.info/dia/pdf/c13/c130276.pdf

Çamdibi, H. M. (2014). Şahsiyet terbiyesi ve Gazali. Çamlıca Yayınları

Çelikel, B. (2006). Gazali’nin eğitim görüşü. Yayınlanmamış doktora tezi. Dokuz Eylül Üniversitesi Sosyal Bilimler Enstitüsü, https://doi.org/10.16953/deusosbil.480956

Demircioğlu, A. (2014). İbn Haldun'un insan düşüncesi ve medeniyet algısı. Gece Kitaplığ1

Diyanet İşleri Başkanlığı [DİB]. (2016). Kur'ân meali. https://kuran.diyanet.gov.tr/mushaf. https://doi.org/10.3726/978-3-653-04104-0/22

Doğan, R. ve Ege, R. (2017). Din eğitimi el kitabı. (5. Bask1). Grafiker Yayınları

Dodson, F. (1999). Çocuğunuzu tanıyor musunuz? Ravza Kitap

Durakoğlu, A. (2014). Gazali’de ahlak eğitimi. Gazi Üniversitesi Eğitim Fakültesi Dergisi GEFAD / GUJGEF 34(2), 211-226. http://www.gefad.gazi.edu.tr/tr/issue/6729. https://doi.org/10.17152/gefd.32829

Duygulu, S. (2010). Çocuklarınıza otokontrol kazandırmak ve çocukları ikna etme yöntemleri. https://www.tavsiyeediyorum.com/makale_4691.htm

Ebu Davud. (2008). Sünen-i Ebî Davud ve tercümesi. https://archive.org/details/EBUDAVUD_201405/page/n2819/mode/2up

El-Affani, S. B. H. (2007). Korku ve ümit arasında nasıl yaşayabilirim? Karınca Polen Yayınları

Erzurumlu İbrahim Hakk1 (2019). Marifetname (2. Baskı). Ataç Yayınları

Gazali. (Trh.). Mizan'ül amel: İlahi saadet. Çeviren: Ömer Dönmez, Hazırlayan: Mevlüt Karaca. Hisar Yayınevi

(2001). Çocuk nasıl yetiştirilir? Üsküdar Yayınevi

(2004). İhya'u ulumid'din. Tezhip ve tekmil: Abdulhalık Duran. Hikmet Neşriyat

(2012). İlme teşvik. Çeviren: Ayhan Okumuş. Neda Yayınları

(2014). İslam'da eğitim. Çeviren: Halil İbrahim Delen. Sır ve Hikmet Yayınları

(2015). Kimya - yı saadet. Çeviren: Ali Arslan. Ataç Yayınları

(2020). El-Munkız mine'd-dalal (Dalaletten hidayete). Çağdaş Kitap

Hassan, Ü. (2019). İbn Haldun: Metodu ve siyaset teorisi. Doğu Batı Yayınları

Işık, Ü. (2018). Çocuklarda okul korkusuna dikkat.

http://hastane.sdu.edu.tr/haber/5786/cocuklarda-okul-korkusuna-dikkat

İbn Haldun. (2009). Mukaddime. Hazırlayan: Süleyman Uludağ. Dergâh Yayınları

(2011). Bilim ile siyaset arasında hatıralar. Dergâh Yayınları

İbn Mace (2015). Sünen-i İbn Mace tercümesi ve şerhi. Hazırlayan: Haydar Hatipoğlu. Ravza Yayınlar1

Kamhi, B. (2013). Çocuğun arkadaş seçiminde ailenin önemi. https://www.tavsiyeediyorum.com/makale_11556.htm 
Karlığa, H. B. (1996). “Gazzali” TDV İslam Ansiklopedisi, Cilt: 13, 518-530. https://islamansiklopedisi.org.tr/arama/?q=Gazali\&p=m

Köylü M. ve Altaş, N. (2019). Din eğitimi. Ensar Neşriyat

Makdisi, G. (2018). Orta çağ’da yüksek öğretim (2. Bask1). Çeviren: A. H. Çavuşoğlu, H. T. Başoğlu. Gelenek Yayınları

(2019). İslam'ın klasik çağında din, hukuk, eğitim (2. Baskı). Çeviren: H. T. Başoğlu. Klasik Yayınları

Medimagazin (2019). Türkiye'de obeziteye bağlı hastalıklarda kişi başına 99 dolara harcanacak. https://www.medimagazin.com.tr/guncel/genel/tr-turkiyede-obeziteye-bagli-hastaliklardakisi-basina-99-dolar-harcanacak-11-681-83719.html

Morris, J. W. (2009). An Arab Machiavelli? Rhetoric, philosophy and politics in Ibn Khaldun's critique of sufism. Harward Middle East and Islamic Rewiew 8 (2009), 241-291. http://cmes.fas.harvard.edu/files/cmes/files/hmeir08_pp242-292.pdf

Nair, A. (2018). Havf ve haşyet kavramlarının Kur'ân'daki semantik anlamı. Pamukkale Üniversitesi Ilahiyat Fakültesi Dergisi Mart/2018, 5(9), 55-98. https://doi.org/10.17859/pauifd.401141

Nergiz Televizyonu [NTV] (2019). Obez insanların sağlık harcamaları 2,5 kat fazla (OECD raporu). https://www.ntv.com.tr/saglik/obez-insanlarin-saglik-harcamalari-2-5-kat-fazlaoecd-raporu,ZpKFrM_dlEC7KTDX9NZlsw. https://doi.org/10.14520/adyusbd.477571

Ogelman, H. G. (2014). Çocuk ve çevre: Küçük çocuklar ve çevre eğitimi el kitabı. Eğiten Kitap

Okumuş, E. (2006). İbn Haldun'un Osmanlı düşüncesine etkisi. İslami Araştırmalar Dergisi. Sayı: 15 , 141-185. http://www.isam.org.tr/documents/_dosyalar/_pdfler/islam_arastirmalari_dergisi/sayi15/14 1_185.pdf adresinden 15.02.2020

Oruç, C. (2009). İmam-1 Gazali'nin eğitim görüşü. Yayınlanmamış doktora tezi. Marmara Üniversitesi Sosyal Bilimler Enstitüsü

Oruç. C. (2010). İbn Haldun'un Mukaddimesinde öğrenme. Selçuk Üniversitesi İlahiyat Fakültesi Dergisi, $\quad$ Bahar 2010, Say1: $29, \quad$ 129-142. https://dergipark.org.tr/tr/pub/neuifd/issue/19691/210325

Oktay, A. (2018). Değerler çocuklara nasıl kazandırılır? https://www.cocukludunya.com/uzmanyazilari/cocuklara-degerler-egitimi-nasil-verilmeli.html

Özcan, Y. S. (2019). Değerler eğitimi nasıl olmalıdır? https://www.trtcocuk.net.tr/ebeveynakademisi/okul-ve-ogrenme/degerler-egitimi-nasil-olmali https://doi.org/10.14527/9786052419939.01

Pedagoji Derneği. (2013). Çocuk eğitiminde ödül ve övgü. Makale No: 10, https://pedagojidernegi.com/cocuk-egitiminde-odul-ve-ovgu/. https://doi.org/10.14527/9786053185475.06

Sağlık Bakanlığg $\quad[\mathrm{SB}] \quad$ (2020). Sağlık bakanlı̆̆g 2020 bütçesi. https://www.saglik.gov.tr/TR,58511/saglik-bakanligi-2020-butcesi-tbmm-plan-butcekomisyonunda-kabul-edildi.html. https://doi.org/10.32709/akusosbil.449527

Sarıbaş, H. (2010). Kantian alturism in economics and Ibn Khaldun. Munich Personal Repec Archive. Paper No: 26904, posted 25. https://mpra.ub.unimuenchen.de/26904/1/ibn_haldun.pdf 
Satı el - Husri. (2001). İbn Haldun üzerine araştırmalar. Dergâh Yayınları

Şener, N. (2006). Çocuk eğitim rehberi: Huzur Yayın Dağıtım

Şulul, K. (2011). İbn Haldun'a göre İslam medeniyeti. İnsan Yayınları

Tirmizi. (2007). Sünen - i Tirmizi. Hazırlayan: Abdullah Parlıyan. Konya Kitapçılık

Toku, N. (2002). İlm-i umran: İbn Haldun'da toplum bilimsel düşünce. Akçağ Kitabevi

Tongar, H. K. (2018). Korkutarak değil, sevdirerek din eğitimi. Hayy Kitap

Tutal, O. (2018). Yaşl11ık, yaşam çevresi ve evrensel tasarım. https://www.researchgate.net/publication/322775610_Yaslilik_Yasam_Cevresi_ve_Evrens el_Tasarim. https://doi.org/10.14527/9786053644538

Turan, İ. ve Nazıroğlu, B. (2020). Din eğitimi. Bilay Yayınları

Uludağ, S. (1996). "Gazzali" maddesi. TDV İslam Ansiklopedisi, Cilt: 13, 518-530. https://islamansiklopedisi.org.tr/gazzali

(2000). Bir düşünür olarak Gazali. İslami Araştırmalar Dergisi, 13(3-4), 249-254. http://www.islamiarastirmalar.com/magazine/tr-bir-dusunur-olarak-gazali318.html?page=archive. https://doi.org/10.33406/molesto.423423 . (2014). İbn Haldun: Hayatı - eserleri - fikirleri. Harf Yayınları

Uzun, P. S. (2017). Çocukların korkuları için tavsiyeler. https://www.yenisafak.com/hayat/cocuklarin-korkulari-icin-tavsiyeler-2750597

Uzun, R. (2014). Çocukların medyadan ve medyada korunması çocuklara yönelik etik davranış kurallarının incelenmesi. Akdeniz Iletişim Dergisi (22), 152-167. https://doi.org/10.31123/akil.441955

Ülken, H. Z. (2015). İslam felsefesi kaynakları ve tesirleri: Eski Yunandan çağdaş düşünceye doğru. Türkiye İş Bankası Yayınları

Watt, W. M. (2003). Al - Ghazali: The Muslim intellectual. Kazi Publications Inc.

Yavuzer, H. (2016). Çocuk eğitimi el kitabı. Remzi Yayınevi

Yüksel, E. (2017). Çocuklarda korku sorunu nasıl çözülmeli? https://www.sozcu.com.tr/hayatim/yasam-haberleri/cocuklarda-korku-sorunu-nasilcozulmeli/ 